\title{
Sistem Informasi Arkeologis
}

\section{Nurhadi Rangkuti}

Keywords: spatial, area, method, theory, practices, planning, GIS

\section{How to Cite:}

Rangkuti, N. (2000). Sistem Informasi Arkeologis. Berkala Arkeologi, 20(1), 54-65. https://doi.org/10.30883/jba.v20i1.807

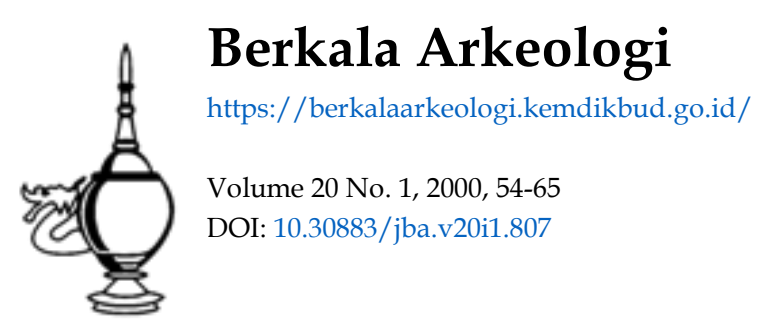

\section{(c) (i) (9)}

This work is licensed under a Creative Commons Attribution-NonCommercial-ShareAlike 4.0 International License. 


\title{
SISTEM INFORMASI ARKEOLOGIS
}

\author{
Nurhadi Rangkuti \\ (Balai Arkeologi Yogyakarta)
}

\section{Pendahuluan}

Pada Evaluasi Hasil Penelitian Arkeologi 1994 (EHPA 1994) di Palembang, Pusat Arkeologi telah merekomendasikan untuk membentuk Sistem Informasi Arkeologis (SIA) yang berbasis komputer. Pembentukan sistem informasi itu merupakan tidak lanjut dari hasil penyusunan database penelitian arkeologi di lingkungan Puslitarkenas, yang telah dimulai sejak tahun 1985 yang dipublikasikan dalam Rapat Evaluasi Metode Penelitian Arkeologi II (REMPA II) di Pandeglang, Jawa Barat. Data base merupakan koleksi data yang saling terkait, disimpan untuk melayani berbagai aplikasi. Penyimpanan data dilakukan untuk memberikan kebebasan pemanfaatan data dengan mengunakan bermacam program, dan struktur data mengikuti perkembangan aplikasi di masa depan. Semua database disimpan dalam bank data, yaitu dalam scbuah file yang menyeluruh, dan disimpan dengan menggunakan alat yang mempunyai akses langsung, yaitu komputer. Data yang disimpan tersedia untuk sejumlah besar pemakai dengan menggunakan sambungan (remote terminals), dan terus menerus dilakukan pemutakhiran (updating) (Richard dan Ryan 1985).

Selama ini Puslitarkenas telah menyusun database hasil analisis artefak dan feature. Data base penelitian tersebut menyimpan informasi deskriptif tentang karakteristik atau atribut-atribut temuan. Akan tetapi belum dilakukan perancangan data base arkeologi dalam acuan spatial yang berbasis komputer. Padahal data dan informasi arkeologis memiliki tiga dimensi, yaitu bentuk (form), ruang (space) dan waktu (time). Hal inilah antara lain yang menyebabkan sampai saat ini belum tersusun sistem informasi arkeologis yang outputnya dapat dijadikan landasan untuk pengambilan keputusan dan penentuan kebijakan, khususnya dalam kegiatan penelitian dan pelestarian data arkeologi.

Untuk merancang SIA perlu mempetimbangkan beberapa hal yang penting. Hal yang pertama adalah bahwa setiap sistem informasi memiliki tujuan. Dalam pembahasan ini sistem informasi adalah sekumpulan prosedur organisasi yang pada saat dilaksanakan akan memberikan informasi bagi pengambil keputusan dan/atau untuk mengendalikan organisasi (Lucas Jr, 1987). Apakah tujuan Sistem Informasi Arkeologis? SIA dirancang untuk memecahkan masalah-masalah metodologi arkeologi dan juga untuk memberikan informasi yang berhubungan dengan arkeologi untuk acuan dalam pengambilan keputusan dalam sebuah organisasi. SIA adalah sebuah sistem informasi 
berbasis komputer yang digunakan untuk menyimpan, mengelola dan menganalisis informasi arkeologis tanpa kehilangan tiga dimensi datanya (formal, spasial, temporal).

Sebagaimana sistem informasi, SIA mempunyai input dan output dan mengubah input untuk menghasilkan output. Untuk hal yang kedua ini perlu dilakukan perancangan untuk menentukan input, output dan pengolahannya, sampai pada pemilihan perangkat keras (hardware) dan perangkat lunak (software) komputer.

Dalam makalah dibahas perancangan SIA dengan aplikasi Sistem Informasi Geografis (SIG).

\section{Sistem Informasi Geografis}

Sistem Informasi Geografis (SIG) adalah sistem informasi berbasis komputer yang memadukan proses pengumpulan, penyimpanan, dan manipulasi data (pengolahan dan analisis data) yang menurunkan informasi baru dalam acuan spasial (georeferenced data) (Jatmiko 1996). SIG merupakan hasil "perkawinan" antara Computer Assisted Cartography (CAC) dan teknologi database ( Bernhardsen 1992).

Konsep dasar SIG dapat digambarkan dalam bentuk piramid (lihat Gambar 1). Data yang diperoleh dari dunia nyata (real world) atau lokasi geografis, dapat disimpan dan diproses dalam komputer untuk selanjutnya ditampilkan dalam bentuk-bentuk yang telah"disederhanakan" untuk keperluan-keperluan tertentu. Berbagai fungsi yang terdapat dalam SIG digunakan untuk menganalisis dan "menyederhanakan" data geografis dari "dunia nyata", dan hasilnya menjadi landasan untuk "piramid pengambilan keputusan".

Dewasa ini proses pengisian bagian atas piramid, yaitu pembentukan model-model, simulasi-simulasi dan skenario-skenario berdasarkan hasil analisis dan penyaringan data, terus dikembangkan. 


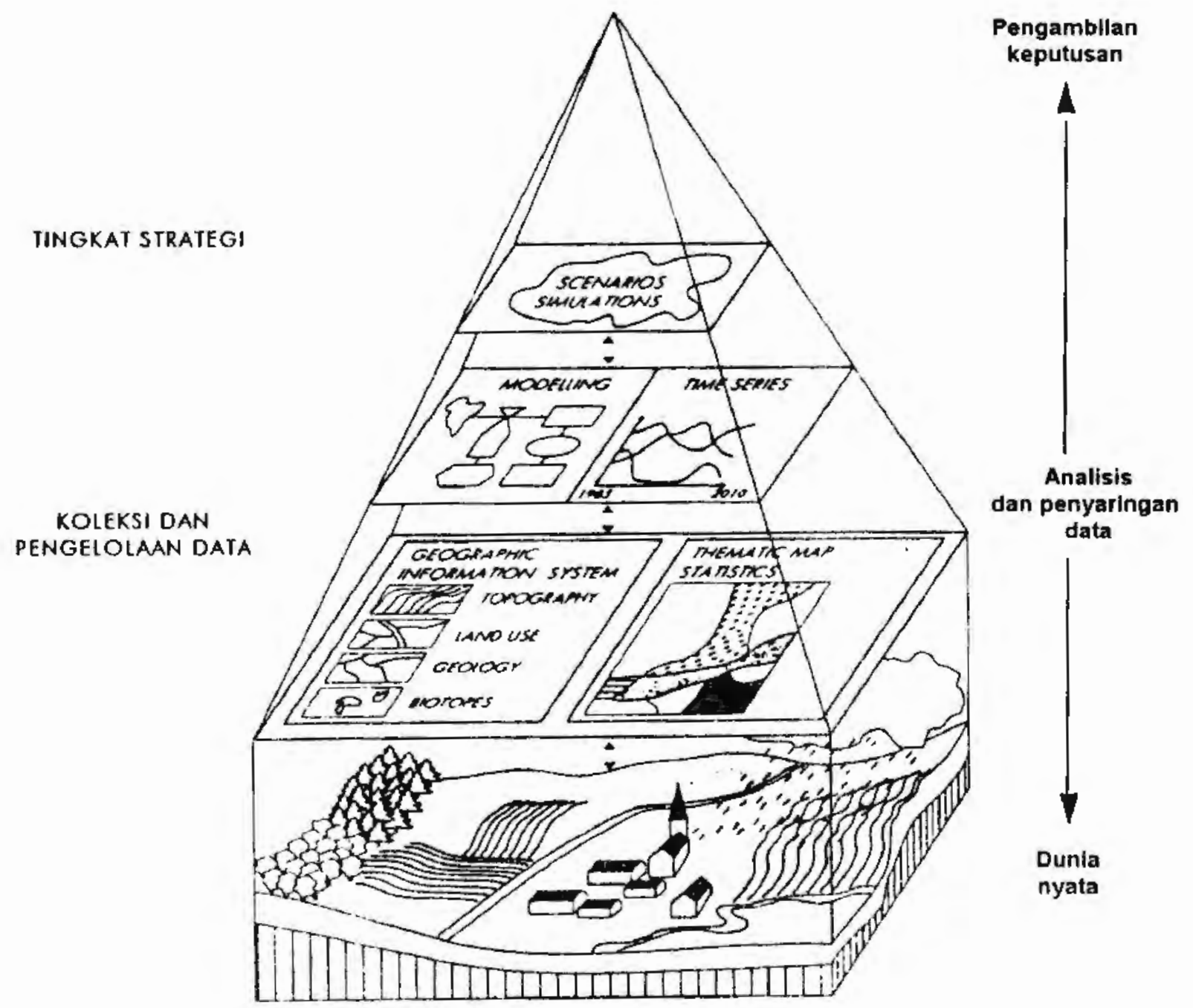

Gmb 1. Konsep Dasar Sistem Informasi Geografis (Sumber: Bernhardsen 1992)

Sebagaimana sistem informasi lainnya, SIG terdiri atas beberapa komponen, yaitu komponen masukan data, pengelolaan data, manipulasi dan analisis data, dan luaran data (data output). Secara garis besar komponen tersebut dapat diuraikan sebagai berikut:

\section{a. Masukan data (data input)}

Data yang diinput berupa (a) data dengan acuan spasial (spatial data) dan (b) data non spasial atau yang disebut data atribut (attribute data). Data spasial berkaitan dengan dimensi fisik dan lokasi geografis. Bentuk data yang menunjukkan lokasi keruangan berupa notasi titik (point), garis (line) dan poligon atau area. Semua data dari kenampakan dan fenomena geografi dapat digambarkan melalui salah satu bentuk notasi tersebut (Dulbahri 1996). Data spasial diperoleh dari peta, foto udara dan citra landsat. 
Data atribut adalah informasi deskriptif mengenai atribut-atribut/karakteristik fenomena geografis. Sebagai contuh: dataran aluvial dengan karakteristik tertentu (topografi, tanah, tekstur tanah, $\mathrm{pH}$ dsb).

Selain kedua data tersebut, informasi geografis juga selalu terikat oleh dimensi waktu, sehingga dalam analisisnya terdapat pula analisis temporal, dimana aktualisasi data ditentukan oleh waktu (Dulbahri 1996).

Struktur data spasial terdiri atas struktur data raster dan struktur data vektor. Data raster terdiri dari susunan sel dalam bentuk grid (grid cells) atau pixel (picture elements) yang setiap pixel mempunyai nilai tertentu. Data vektor adalah data spasial yang disimpan dalam struktur geometris tertentu, dengan memisahkan informasi titik, garis, poligon dan jaringan (network).

Pemasukan data spasial dalam SIG pada prinsipnya adalah pengubahan format data dari analog ke digital (Jatmiko 1996). Data analog yang berupa notasi-notasi titik, garis dan poligon yang terdapat dalam peta dan foto udara diubah menjadi data digital, yang langsung dapat diolah dalam komputer.

\section{b. Pengelolaan data}

Pengelolaan data meliputi fungsi-fungsi yang diperlukan untuk menyimpan dan menimbun data dari database, baik database spasial maupun data base atribut.

Dalam bentuk peta kertas, informasi-informasi geografis biasanya tersaji dalam sekumpulan tema, seperti peta jalan, peta penggunaan lahan, atau peta administratif. Peta-peta tematik tersebut berisi data spasial dan atribut-atributnya. Dalam SIG berbasis komputer, pengelolaan sekumpulan informasi yang bersifat tematis tersebut disimpan dalam layer-layer data (data layer) yang berbeda. Sebuah layer data terdiri atas sekumpulan informasi geografis dan karakteristiknya yang secara logika saling berhubungan (Aronoff 1989). Sebagai contoh, jalan raya dan jalan kereta api dapat digabungkan sebagai sebuah layer data yang bernama jaringan transportasi; atau sungai dan danau sebagai layer data hidrologi. Dalam analisis spasial, layer-layer data ini ditumpangsusun sehingga menghasilkan informasi baru dalam acuan spasial.

\section{c. Manipulasi dan analisis data}

Fungsi-fungsi untuk manipulasi dan analisis data yang dimiliki SIG dapat dikelompokkan dalam empat bagian (Aronoff 1989), yaitu:

- penyimpanan dan analisis data spasial, antara lain pengubahan format data (dari raster ke vektor dan sebaliknya); pengubahan geometrik dengan registrasi data koordinat (posisi absolut situs) dan posisi relatif situs; pengubahan proyeksi peta, misalnya dari proyeksi azimuth ke UTM.

- penyimpanan dan analisis data atribut, berupa pengeditan dan pemanggilan data. 
- analisis yang mengintegrasikan data spasial dan data atribut. Analisis meliputi pencarian, klasifikasi, pengukuran; tumpang susun (overlay) layer-layer data (peta-peta tematik) ; interpolasi, serta fungsi-fungsi untuk analisis "connectivity" (hubungan antar jalur untuk menentukan jalur yang paling efisien untuk dilalui) pada suatu lokasi geografis yang direkam dalam layer data atau peta.

- pembuatan format laporan (output formatting) yaitu mempersiapkan hasil-hasil analisis untuk laporan (peta, tabel, dan teks). Pembuatan format peta meliputi judul peta, keterangan, skala, panah arah utara, pemberian teks dalam peta (misal nama kota, desa, sungai, situs arkeologi), pemilihan warna untuk titik, garis dan poligon, dan simbol-simbol grafis untuk keterangan peta.

\section{d. Luaran data}

Luaran data menayangkan informasi maupun hasil analisis data geografis secara kualitatif maupun kuantitatif. Luaran data atau laporan dapat berupa peta, tabel dan teks, baik dalam bentuk cctakan (hard-copy) maupun arsip clektronik (soft-copy). Laporan-laporan digunakan untuk perencanaan dan pengambilan keputusan.

\section{e. Perangkat keras dan perangkat lunak}

Sebagaimana sistem informasi berbasis komputer yang lain, SIG juga memerlukan perangkat keras (hardware) dan perangkat lunak (software) yang mendukungnya. Perangkat keras yang diperlukan yaitu (1) komputer atau CPU, (2) terminal display dan keyboard, (3) graphic display dengan keyboard, grapphic tablets, joy-stick, dan mouse, (4) digitizer dan scanner, (5) printer warna, (6) plotter.

Perangkat lunak SIG sudah banyak dikembangkan. Dewasa ini di Indonesia telah digunakan berbagai macam perangkat lunak SIG, seperti ARC/INFO, ERDAS, TIGRIS, SYSSCAN, SYNERCOMP, SPAN, HUNTER, ILWIS, MICROBRYAN.

\section{Pembentukan SIA}

Aplikasi SIG dalam arkeologi pada intinya adalah untuk memecahkan masalahmasalah metodologis dalam menganalisis data arkeologi tanpa kchilangan kualitas informasi tiga dimensi arkcologi, yaitu bentuk (form), ruang (space) dan waktu (time) (Green 1990; Rangkuti 1996a). Tujuan utama aplikasi SIG dalam penelitian arkeologi adalah untuk menciptakan kembali bentang budaya masa lalu, dalam sebuah kerangka berorientasi masalah (problem oriented framework). Selain untuk kepentingan penelitian (research), SIG dapat digunakan untuk kepentingan pelestarian dan pemanfaatan sumberdaya arkeologis atau benda cagar budaya (BCB). Aplikasi SIG dalam arkeologi bermanfaat antara lain untuk:

$\Rightarrow$ merekonstruksi bentang budaya masa lalu (archaeological landscape) 
$\Rightarrow$ membentuk model analisis pola permukiman kuna (masa prasejarah, masa klasik, masa Islam dan masa Kolonial)

$\Rightarrow$ memprediksi lokasi situs yang belum diketahui/ditemukan berdasarkan analisis situs-situs yang telah diketahui/ditemukan pada sebuah wilayah.

Perancangan database arkeologis yang mencakup tiga dimensi data arkeologis (formal, spasial dan temporal), merupakan landasan untuk membentuk SIA. Tiga dimensi arkeologis terscbut sesuai dengan tiga karakteristik dasar data geografis, yaitu data spasial, data atribut, dan data temporal (lihat Gambar 2).

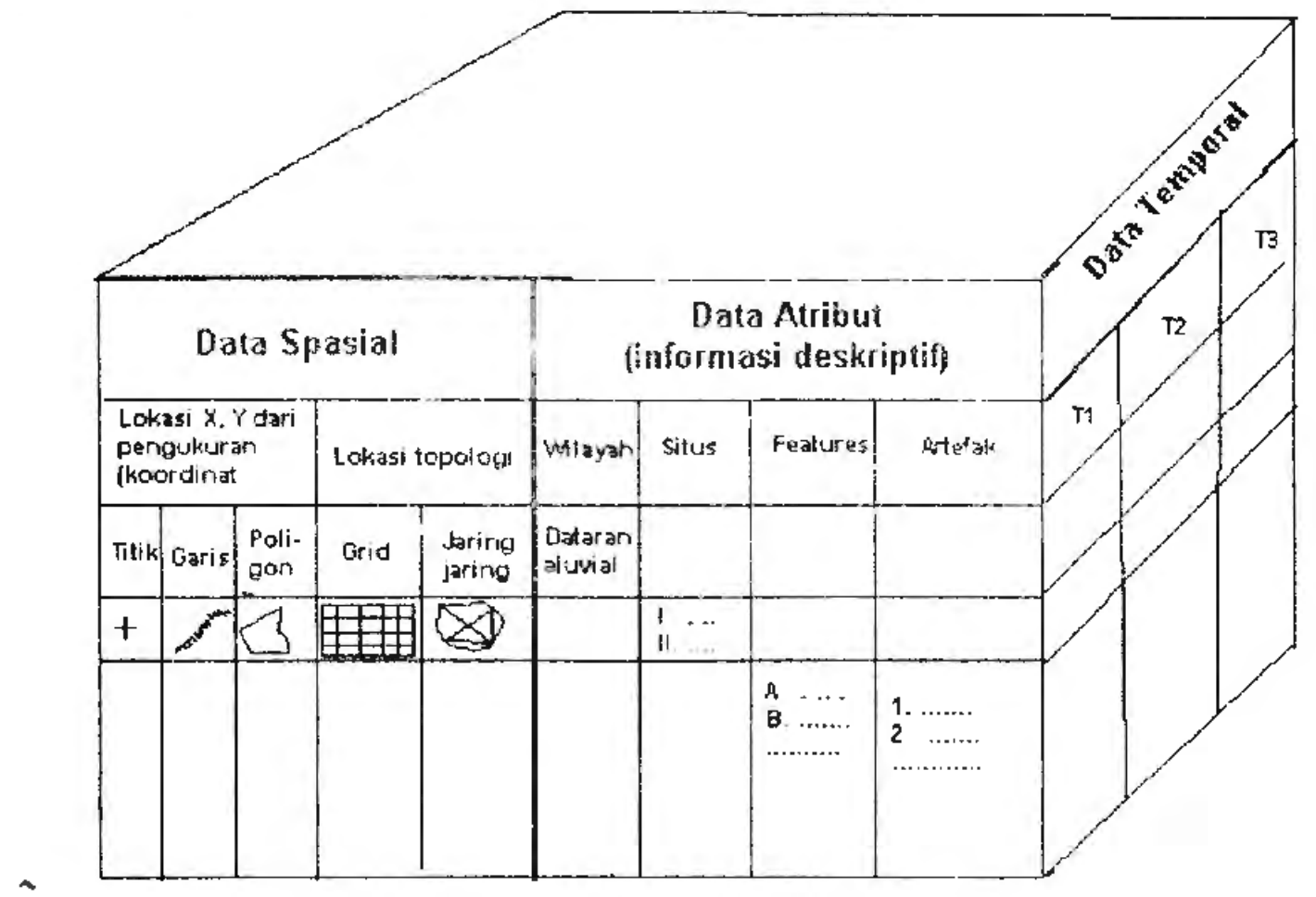

Gmb 2: Tiga karakteristik informasi arkeologis (After Stine dan Lanter 1990).

\section{a. Dimensi Spasial}

Sebagaimana diketahui entitas arkeologi (archaeological entities) yang mendasar adalah artefak dan "feature". Artefak adalah benda budaya yang bergerak (moveable) yang menunjukkan bukti aktivitas manusia masa lalu. Feature dipandang sebagai benda budaya tidak bergerak (unmoveable) yang berada dalam keadaan in situ atau tidak dapat dilepaskan dari matriksnya (dalam konteks nuang). Termasuk dalam feature mulai dari monumen-monumen, pondasi bangunan, sampai lubang sampah yang ditemukan dalam penggalian arkeologis. 
Informasi arkeologi dalam dimensi spasial mencakup hubungan keruangan antara (a) artefak dengan features, (b) artefak dan features hubungannya dengan situs, dan (c) situs dengan wilayah (region). Dengan demikian situs adalah kelompok atau himpunan artefak dan features. Batas dan luas situs dapat ditentukan berdasarkan distribusi artefak dan feature. Wilayah adalah sebuah area yang dapat ditentukan batas dan luasnya serta dimensi waktunya berdasarkan persebaran situs dan hubungan antar situs. Wilayah dapat didelineasi berdasarkan karakteristik geografisnya (misal bentuklahan, topografis). Sebagai contoh: peneliti dapat mengamati persebaran dan hubungan antar situs prasejarah di wilayah dataran aluvial. Dataran aluvial tersebut dapat didelineasi sehingga dapat dibedakan dengan wilayah lainnya, seperti wilayah perbukitan.

\section{b. Dimensi non spasial (data atribut)}

Data spasial terkait dengan atribut-atribut nonspasialnya untuk mendeskripsikan karakteristik penting fenomena geografis dan arkeologis yang ada di lokasi (real world). Data atribut yang dimaksud seperti jenis-jenis artefak dan/atau feature dengan klasifikasi bahan, berat, tinggi, jumlah, dan sebagainya. Selain itu data atribut meliputi pula deskripsi mengenai karakteristik fenomena geografis, misalnya jenis tanah, tekstur, $\mathrm{pH}$ dan sebagainya. Data atribut dapat disimpan dalam bentuk database.

\section{c. Dimensi temporal}

SIG digunakan untuk menganalisis perubahan informasi spasial dari waktu ke waktu pada sebuah wilayah. Sebuah situs kota dapat diklasifikasi bentangnya menurut tahaptahap pembangunannya, sehingga dapat diketahui distribusi bangunan dan jalan dari waktu T1 hingga waktu T2. Demikian pula suatu wilayah tertentu memiliki informasi spasial yang berbeda bila dilihat dari penjamanan situs-situs yang tersebar di permukaan tanahnya (situs prasejarah, situs Hindu-Buddha dan Situs masa Islam).

\section{d. Pengorganisasian data untuk analisis}

Informasi-informasi arkeologis dapat disusun dalam layer-layer data yang berbeda disesuaikan dengan tema penelitian maupun untuk menyusun model-model yang dikehendaki dari hasil analisis. Contoh layer-layer data untuk penelitian arkeologiperkotaan dapat dilihat pada Lampiran 1. Dengan kata lain, layer-layer data ditentukan oleh variabel-variabel yang diteliti dalam suatu penelitian.

\section{Penutup}

Pembentukan SIA dengan aplikasi SIG merupakan suatu tantangan karena sarat dengan kendala. Kendala yang nyata adalah terbatasnya alat (hardware dan software) dan minimnya tenaga terlatih. Selain itu peralatan dan sistem yang baru akan mempengaruhi jalannya suatu organisasi. Untuk dapat melaksanakan SIA dengan baik 
tidak hanya diperlukan investasi pada komputer, digitizer, plotter, printer warna, perangkat lunak SIG sendiri, serta data spasial (peta, foto udara, citra satelit), tetapi juga melatih manajer, perencana dan pengumpul data dalam menggunakan teknologi baru pada kaitan yang tepat.

Dengan terbentuknya SIA berbasis komputer, diperlukan adanya semacam "departemen komputer" di lingkungan Pusat Arkeologi, yang khusus menangani masalah disain sitem informasi dan analisis sistem tersebut.

\section{KEPUSTAKAAN}

Aronoff, Stan, 1989, Geographic Information System: A Management Perspective, Ottawa, Canda: WDL Publications.

Bernhardsen, Tor, 1992, Geographic Information System, Norwegian Mapping Authority.

Crumley, Carol L dan William H. Marquardt, 1990, Landscape: A Unifying Concept in Regional Analysis, dalam Interpreting Space: GIS and Archaeology (ed.Kathleen M.S. Allen), Taylor and Francis, London-New YorkPhiladelphia.

Green, W. Stanton, 1990, Approaching Archaeological Space: An Introduction to the Volume, dalam Interpreting Space: GIS and Archaeology (ed.Kathleen M.S. Allen), Taylor and Francis, London-New York-Philadelphia.

Jatmiko, Retnadi Heru, 1996, Input Data dalam Sistem Informasi Geografis, Handout Pelatihan Sistem Informasi Geografi Angkatan ke-4, di Yogyakarta 19-31 Agustus 1996, Fakultas Geografi Univ. Gadjah Mada di Yogyakarta.

Karmono Mangunsukardjo, 1996, Inventarisasi dan Evaluasi Sumberdaya Lahan, dipersiapkan untuk Pelatihan Interpretasi Citra Penginderaan Jauh dan Sistem Informasi Geografis, 5 Agustus - 4 November 1996, Kerjasama Fakultas Geografi Universitas Gadjah Mada dengan Departemen Transmigrasi dan Permukiman Perambah Hutan, di Yogyakarta.

Rangkuti, Nurhadi, 1996a, Arkeologi Terapan dan Masa Depannya di Indonesia, dalam Pertemuan Ilmiah Arkeologi VII, Cipanas 12-16 Maret 1996, Jakarta: Proyek Penelitian Arkeologi Jakarta 1997-1998. 
Rangkuti, Nurhadi, 1996b, Aplikasi Sistem Informasi Geografis dalam Penelitian Arkeologi Skala Wilayah, dalam Jurnal Penelitian Arkeologi Nomor 04, Yogyakarta: Balai Arkeologi.

1997, Penelitian Arkeologi Dalam Kaitannya dengan Pelestarian Benda Cagar Budaya, Buletin Arkeologi Amoghapasa, nomor 6/III/Maret 1997, Suaka Peninggalan Sejarah dan Purbakala Provinsi Sumbar dan Riau.

1999, Evaluasi Kawasan Sumberdaya Arkeologis: Usulan Model Kajian Arkeologi Terapan, dalam Pertemuan Ilmiah Arkeologi VIII, Yogyakarta, Februari.

Rangkuti, Nurhadi dan Novida Abbas, 1994, Pangkalan Data Arkeologi dan Pembentukan Sistem Informasi Arkeologi, dalam Evaluasi Hasil Penelitian Arkeologi di Palembang, September.

Scovill, Douglas H., Garland J. Gordon dan Keith M. Anderson, Guidelines for the Preparation of Statesments of Environmental Impact on Archaeological Resources, dalam Conservation Archaeology A Guide For Cultural Resource Managements Studies (ed. Michael B. Schiffer dan George J. Gumerman), New York: Academic Press.

Stine, Roy S. dan David P. Lanter, 1990, Considerations for Archaeology Database Design, dalam Interpreting Space: GIS and Archaeology (ed.Kathleen M.S. Allen), Taylor and Francis, London-New York-Philadelphia.

Vink, A.P.A. 1983, Landscape Ecology and Landuse, Longman: London New York. 
Lampiran 1. Contoh Layer Data yang digunakan untuk penelitian arkeologi-perkotaan masa kolonial.

\begin{tabular}{|c|c|}
\hline Nama Layer & Atribut-atribut \\
\hline $\begin{array}{l}\text { JARINGAN JALAN (Garis) } \\
\text { Skala }: 1: 25.000\end{array}$ & $\begin{array}{ll}\text { - } & \text { Tipe jalan: } \\
\text { - } & \text { Lebar jalan: } \\
\text { - Kronologi : } \\
\text { - Kapasitas jalan }\end{array}$ \\
\hline $\begin{array}{l}\text { ADMINISTRATIF /ZONA (Poligon) } \\
\text { Skala } 1 \mathrm{~cm}=200 \text { meter }\end{array}$ & $\begin{array}{l}\text { - Daerah permukiman padat: } \\
\text { - Daerah Pecinan } \\
\text { - Daerah pelabuhan : } \\
\text { - Paerah pusat ekonomi: } \\
\text { Penggunaan lahan: }\end{array}$ \\
\hline $\begin{array}{l}\text { TOPOGRAFI (Garis dan titik) } \\
\text { (Input Skala } 1 \mathrm{~cm}=100 \text { meter) }\end{array}$ & $\begin{array}{l}\text { - Ketinggian: } \\
\text { - Kelerengan : }\end{array}$ \\
\hline $\begin{array}{l}\text { BANGUNAN-BANGUNAN KUNA (Poligon) } \\
\text { (Input skala } 1 \mathrm{~cm}: 100 \mathrm{~cm} \text { ) }\end{array}$ & $\begin{array}{l}\text { - Tipe bangunan } \\
\text { - Periode/masa: } \\
\text { - Arsitektur : }\end{array}$ \\
\hline $\begin{array}{l}\text { LINGKUNGAN (Poligon) } \\
\text { (Input skala } 1: 25.000 \mathrm{~s} / \mathrm{d} 1: 50.000 \text { ) } \\
\text { Satuan-satuan bentuklahan }\end{array}$ & $\begin{array}{ll}\text { - } & \text { Jenis tanah : } \\
\text { - } & \text { Vegetasi : } \\
\text { - } & \text { Geologi : } \\
\text { - } & \text { Bentuklahan : }\end{array}$ \\
\hline
\end{tabular}




\section{Lampiran 2. Skema Pendekatan Evaluasi Kawasan Sumberdaya Arkeologis dengan aplikasi SIG (Sumber: Rangkuti 1999: 8).}

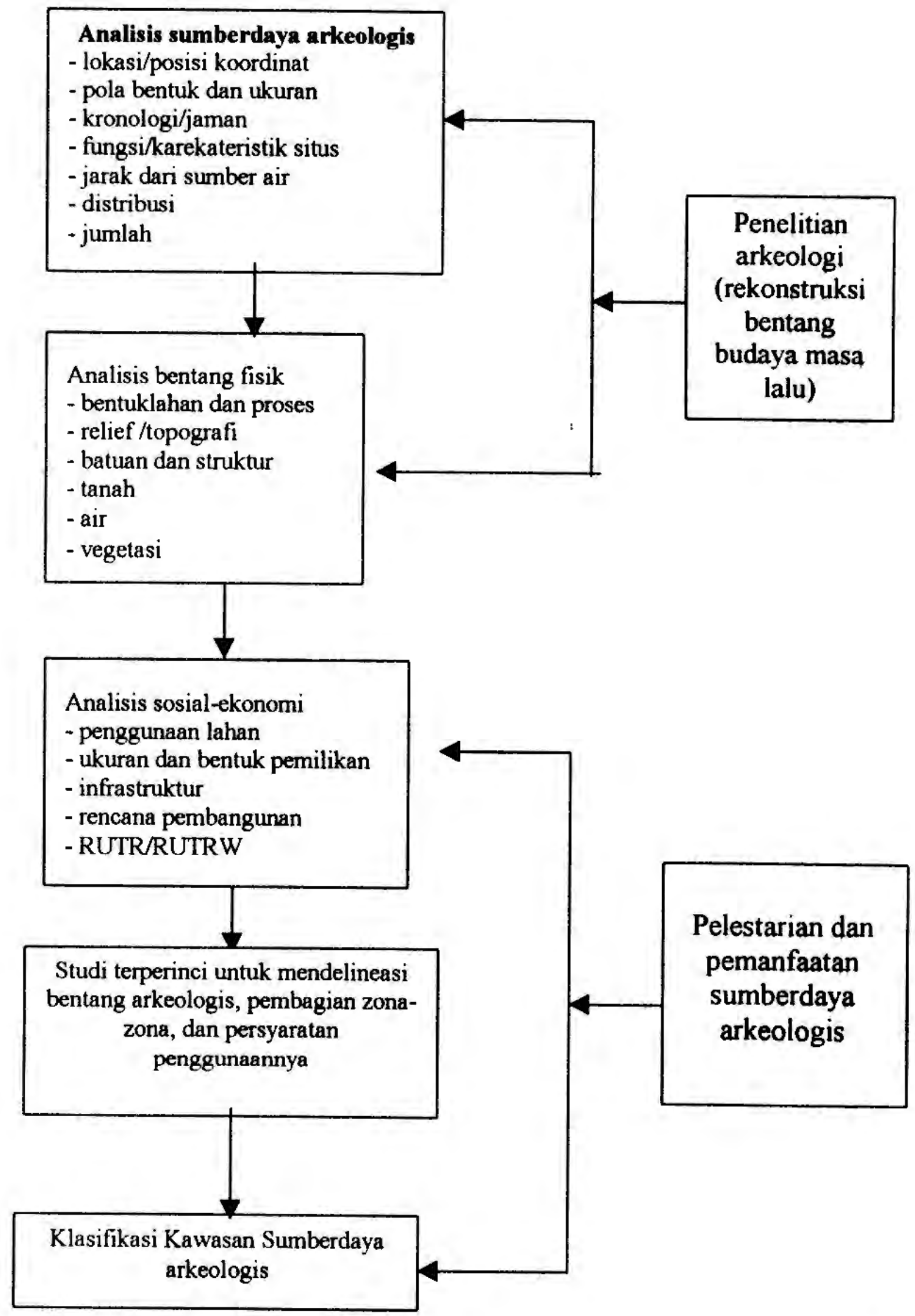




\section{Lampiran 3. Layer Data untuk Evaluasi Kawasan Sumberdaya Arkeologis dengan aplikasi SIG.}

\begin{tabular}{|c|c|}
\hline Nama Layer & Atribut-atribut \\
\hline $\begin{array}{l}\text { SUMBERDAYA ARKEOLOGIS (Titik, Poligon) } \\
\text { Skala }: 1: 50.000 \mathrm{~s} / \mathrm{d} 1: 100.000\end{array}$ & $\begin{array}{l}\text { - Tipe Artefak: } \\
\text { - Tipe Feature: } \\
\text { - Tipe Situs : } \\
\text { - Jumlah : } \\
\text { - Kronologi : } \\
\text { - Luas Situs: }\end{array}$ \\
\hline $\begin{array}{l}\text { TOPOGRAFI (Garis dan titik) } \\
\text { (Input Skala } 1 \mathrm{~cm}=100 \text { meter) }\end{array}$ & $\begin{array}{l}\text { Ketinggian } \\
\text { - Kelerengan : }\end{array}$ \\
\hline $\begin{array}{l}\text { LINGKUNGAN FISIK (Garis, Poligon) } \\
\text { (Input skala } 1: 25.000 \mathrm{~s} / \mathrm{d} 1: 50.000 \text { ) } \\
\text { Satuan-satuan bentuklahan }\end{array}$ & $\begin{array}{l}\text { - Bentuklahan: } \\
\text { - Jenis tanah : } \\
\text { - } \text { Vegetasi : } \\
\text { - } \text { Air permukaan: } \\
\text { - Geologi : } \\
\end{array}$ \\
\hline PENGGUNAAN LAHAN (Poligon) & $\begin{array}{l}\text { - Tipe penggunaan lahan: } \\
\text { - Luas lahan: } \\
\text { - Bentuk kepemilikan }\end{array}$ \\
\hline $\begin{array}{l}\text { PRASARANA (Titik, Poligon) } \\
\text { (Input skala } 1: 25.000 \text { s/d } 1: 50.000 \text { ) }\end{array}$ & $\begin{array}{ll}\text { - } & \text { Tipe Jalan } \\
\text { - } & \text { Tipe bangunan publik } \\
\text { - Pabrik } \\
\end{array}$ \\
\hline
\end{tabular}

